Article

\title{
Community Resistance and Discretionary Strategies in Planning Sustainable Development: The Case of Colorado Cities
}

\author{
William L. Swann ${ }^{1, *}$, Shelley McMullen ${ }^{1,2}$, Dan Graeve ${ }^{1}$ and Serena Kim ${ }^{1}$ \\ ${ }^{1}$ School of Public Affairs, University of Colorado Denver, Denver, CO 80204, USA; E-Mails: william.swann@ucdenver.edu \\ (W.L.S.), shelley.mcmullen@ucdenver.edu (S.M.), dan.graeve@ucdenver.edu (D.G.), serena.kim@ucdenver.edu (S.K.) \\ ${ }^{2}$ College of Architecture and Planning, University of Colorado Denver, Denver, CO 80204, USA \\ * Corresponding author
}

Submitted: 29 July 2019 | Accepted: 27 November 2019 | Published: 27 December 2019

\begin{abstract}
How bureaucrats exercise administrative discretion is an enduring question in urban planning and democratic governance. Conflicts between urban planners' professional recommendations and community stakeholders' demands play out especially in the sustainable development context, where planners confront value conflicts between environmental, economic, and social goals. This article investigates the sources of community resistance to sustainable development and the discretionary strategies planners employ to persuade communities towards a more sustainable future. Utilizing a descriptive case study design, we examine four Colorado cities experiencing growth and community resistance to sustainable development practices. We find that while planners face community resistance from a multitude of sources, including developer pressures, NIMBYism and density concerns, and distrust of the planning profession, planners also work within their discretionary space using interdepartmental coordination, communication and outreach, data and evidence, rule changes, and neutral stewardship to encourage sustainable development. Implications for planning practice and future research are discussed.
\end{abstract}

\section{Keywords}

administrative discretion; community resistance; discretionary strategies; local governance; NIMBY; sustainable development

Issue

This article is part of the issue "Towards Transformative Practice Frameworks: Planners, Professional Agency and Sustainable Urbanism" edited by Nezhapi-Dellé Odeleye (Anglia Ruskin University, UK) and Niamh Murtagh (University College London, UK).

(C) 2019 by the authors; licensee Cogitatio (Lisbon, Portugal). This article is licensed under a Creative Commons Attribution 4.0 International License (CC BY).

\section{Introduction}

While urban planning involves designing formal documents, regulations, and codes concerning land use and the built environment, it is much more about ethical judgment, consensus-making, communication, and participatory processes (Arnstein, 1969; Campbell, 2002; Forester, 1980, 1989; Innes \& Booher, 1999). To better engage citizens and address complex societal problems, planners are advised to draw on their professional knowledge, or specialized expertise gained through university or scientific-based training, as well as their local knowledge, or understanding of community context, characteristics, and meaning through citizen interaction and lived experience (Corburn, 2003).

Coupling local knowledge with professional expertise is important because public planners in democratic societies serve citizens and report to elected or appointed executive leadership and planning committees. As such, planners often tread carefully when making professional recommendations that challenge the tacit expertise of public officials, community stakeholders, and citizens 
(Hoch, 1994). Despite their subordinate status in governments, however, planners-like many bureaucrats (Lipsky, 1980)-operate within a discretionary space or "the area in which agents are at liberty to make practical judgments and choices about how to act" (Forsyth, 1999, p. 6). Within this discretionary space, how do planners apply their limited discretion to promote decisions with "special concern for the long-range consequences of present actions" (American Planning Association, 2016)?

Planning sustainable development which "meets the needs of the present without compromising the ability of future generations to meet their own needs" (Brundtland, 1987, p. 16) is not always consistent with the policy preferences in local communities and involves inherent value conflicts among economic, ecological, and social equity goals (Campbell, 1996; Godschalk, 2004). Similar to the tension between bureaucratic expertise and democratic governance (Fischer, 2000), misalignment between planners' recommendations and local demands can hinder the pursuit of sustainable development. The NIMBY (Not-In-My-Back-Yard) phenomenon, for example, has challenged planners aiming to tackle environmental, health, and social problems for decades, across the industrialized world (Lake, 1993). NIMBYism concerns essential land uses that are perceived by local residents to have a concentrated, detrimental effect on property values or quality of life, even if such use benefits the community at large (Wallis, 2008).

NIMBYism is a longstanding obstacle to sustainable development in the form of higher-density living, renewable energy deployment, public transit expansion, or affordable housing. But planning and policy decisions enhancing sustainability can threaten not only landowners but also businesses, elected leaders, and other community stakeholders who hold onto narrow or particularistic interests (Lubell, Feiock, \& Ramirez, 2005). Sustainable development is difficult to attain in practice because of fragmented interests, imbalanced power structures, and lack of political will (Hawkins, 2014a; Wheeler, 2000). While compact, energy-efficient, accessible, and affordable development is needed to enhance sustainability, not all stakeholders will agree on the best approach, and the most powerful, organized, and incentivized opposition will work to prevent such activities (Deslatte \& Swann, 2016; Logan \& Molotch, 1987).

Transforming planning ideas into practice thus necessitates political power, communicative strategies, and persuasion (Forester, 1980, 1982, 1989; Hoch, 1994; Taylor, 1998; Wildavsky, 1973). Forester (1989) describes how planners utilize strategies aimed at enhancing diplomacy, building coalitions, or mediating between conflicting parties to support the community's-and their owndevelopment goals. Hoch (1994) also demonstrates how planners push against and leverage political power with persuasion and storytelling to win over support for their recommendations. Achieving sustainable development goals may therefore call for planners to overcome community resistance by utilizing strategies of their own, developed and implemented within their discretionary space, aimed at persuading less-than-sympathetic community stakeholders. Yet we have little understanding of what these processes look like in the contemporary sustainable development context.

In this article we ask two questions: (1) What sources of community resistance to sustainable development do planners perceive? (2) What strategies do planners use within their discretionary space to overcome such resistance? Using a descriptive case study design, we draw data from in-depth interviews with planners in four Colorado municipal governments and find that when planners face community resistance to sustainable development, they engage in interdepartmental coordination, communication and outreach, data and evidence presentation, rule changes, and neutral stewardship to persuade decision makers and citizens to pursue a more sustainable direction for their community.

The following section describes our method. The sources of community resistance planners face and the discretionary strategies they use for persuading their community towards sustainable development are then identified. We then discuss the implications for practice and research. A conclusion follows.

\section{Method}

To investigate the perceived sources of community resistance and the discretionary strategies planners use to encourage sustainable development, this study uses a qualitative, descriptive case study design that aims to describe the theoretical concepts of interest in their real-world context (Yin, 2014). Cases were drawn from Colorado's Front Range Urban Corridor, containing the Fort Collins, Boulder, Denver, Colorado Springs and Pueblo metropolitan areas. Colorado's Front Range, which runs along the Eastern edge of the Rocky Mountains, has served as a useful laboratory for studying sustainable development in recent decades (Godschalk, 2004; Goetz, 2013; Mitchell, Attoh, \& Staeheli, 2015). As a whole, Colorado grew by $13.2 \%$ from 2010-2018, making it the fourth-highest growth state in the U.S. during that time period (Tabachnik, 2018).

\subsection{Case Selection}

Case selection was guided by ensuring variation in city population size, political leaning, household income, educational attainment, racial composition, and form of municipal government, all of which have been empirically linked to sustainable planning and policy decisions at the local level (Lubell et al., 2005; Lubell, Feiock, \& Handy, 2009). Different types of development settlements likely have different demands and experience different development pressures, so we selected cases from a range of central, suburban, and more peripheral, "urban-edge" cities. In total, while eight cities meeting these criteria were sent email invitations to partici- 
pate in interviews, four cities opted to participate in the study. The four cities included one central city, one large suburb, one mid-sized suburb, and one urban-edge city, which varied along political, income, educational, racial, and institutional lines. Characteristics for each city, as well as Colorado and the U.S. for comparison, are reported in Table 1, using 2018 Census estimates (population and form of government were excluded to protect cities' anonymity).

City A, a mid-sized suburb within a major metropolitan area, has experienced steady expansion in its population, economy, and infrastructure, while its residents have been getting older and more diverse in recent years. The city, which leans right politically, has recently focused on developing its historic downtown and expanding higher-density development to serve its role as a commuter city but also offering residents a vibrant place to live. Having mostly single-family homes, the city has experienced resistance to increased density, multifamily housing, and mixed-use development in some neighborhoods, according to city officials interviewed.

City B is a large suburb in close proximity to a central city. Although historically conservative, the city now leans left politically, as its non-white population has grown to become one of the most diverse suburbs in Colorado. In recent decades the city has expanded into its undeveloped land, despite growth limitations due to lacking a central business district and prohibitive water service costs. According to city officials interviewed, there is less community resistance to increasing density relative to other cities in its metropolitan area. The city has also made sustainability an explicit goal in its comprehensive plan.

City $\mathrm{C}$ is a moderately large central city with historically conservative politics and pro-development values. The local economy is bolstered by three key industries, including higher education. Although there have been recent attempts to address infill development and downtown renewal, the city has long focused on developing its outer fringes with numerous annexations since the late 1800 s, resulting in a highly sprawled urban area. Despite having some historic, wealthy neighborhoods, the large influx of new, younger residents has created affordable housing challenges, according to city officials interviewed. The city is also beginning to make improve- ments in stormwater management, sustainable utilities, and green infrastructure, as evidenced in its comprehensive plan.

City $D$ is a small to mid-sized city on the edge of a major metropolitan area. Like many of Colorado's metropolitan cities, it has experienced robust growth in the last decade. The city is conservative politically and considerably wealthier than most cities statewide and nationally. The city predominantly consists of single-family residences and is automobile-centric with few apartment living options, largely due to opposition to higher-density development in the community. Of the four cities, city $D$ has experienced the highest population growth from 2010-2018.

While we expect some similarities across cases due to the cities being subject to the same state laws and institutions, each case may face different sources of community resistance to sustainability and thus necessitate or constrain different discretionary strategies, due to variation in development, fiscal, and interest group indicators (Lubell, Feiock, \& Handy, 2009), civic capacity (Portney \& Berry, 2010), and geographical and natural resource limits (Owens, 1994).

\subsection{Data Collection}

Data were collected from field interviews with 26 local government employees (three in city A, five in city $B, 14$ in city $C$, and four in city D) during the spring of 2019. The number of interviewees is higher in city $C$ due to its larger population and government organization size. A semi-structured questionnaire was prepared prior to the interviews, and the study was approved by an institutional review board prior to conducting interviews. The vast majority of interviewees worked in local planning offices, while a select few worked in related areas such as community engagement, buildings, urban renewal, and environment. Interviewees spanned vertically (directors, middle managers, and frontline staff) and functionally (long-range planning, housing, environment, building, zoning, and land use) within local planning offices. Interviewees were recruited through an initial point of contact (planning directors in most cases) who was asked to identify staff across departmental hierarchy and functions to achieve variation in work perspectives and expe-

Table 1. Characteristics of case cities.

\begin{tabular}{lllllr}
\hline Case & $\begin{array}{l}\text { Development } \\
\text { Settlement Type }\end{array}$ & $\begin{array}{l}\text { \% Democratic Vote } \\
\text { in 2016 Presidential } \\
\text { Election }\end{array}$ & $\begin{array}{l}\text { Median } \\
\text { Household } \\
\text { Income }\end{array}$ & $\begin{array}{l}\text { \% Bachelor's } \\
\text { Degree }\end{array}$ & $\begin{array}{l}\text { \% Non- } \\
\text { White }\end{array}$ \\
\hline City A & Mid-sized suburb & $40 \%-50 \%$ & $\$ 70,000-\$ 80,000$ & $30 \%-40 \%$ & $0 \%-10 \%$ \\
City B & Large suburb & $50 \%-60 \%$ & $\$ 50,000-\$ 60,000$ & $20 \%-30 \%$ & $30 \%-40 \%$ \\
City C & Central city & $30 \%-40 \%$ & $\$ 50,000-\$ 60,000$ & $30 \%-40 \%$ & $20 \%-30 \%$ \\
City D & Urban-edge city & $30 \%-40 \%$ & $>\$ 100,000$ & $50 \%-60 \%$ & $10 \%-20 \%$ \\
Colorado & N/A & $48.2 \%$ & $\$ 65,458$ & $39.4 \%$ & $12.9 \%$ \\
U.S. & N/A & $48.2 \%$ & $\$ 57,652$ & $30.9 \%$ & $23.5 \%$ \\
\hline
\end{tabular}

Notes: City figures are reported in ranges to protect cities' anonymity. N/A = not applicable. 
riences. All interviews were confidential and conducted on-site in private offices. Interviews were recorded with permission and transcribed. To improve the validity of our study (Yin, 2014), we triangulated the interview data by reviewing comprehensive or master plans available on public-facing city websites.

\subsection{Data Analysis}

Interviews were coded by the authors to identify main content themes. We followed Yin's (2016) recommended Level 1 and Level 2 coding procedure, which is similar to Corbin and Strauss's (2015) grounded theory approach that uses "open" and "axial" coding, respectively. In the "disassembling" stage, Level 1 codes were assigned by the authors, sticking closely to the data. This was followed by the authors' assignment of Level 2 codes, which are higher-level categories of initial codes. Patterns were identified by the authors in the "reassembling" stage, and tables were created to organize thematic codes. During the coding process, exemplary quotes from interviews were identified to provide context. City comprehensive and master plans were used to compare against what was said in the interviews, obtain background information, and verify facts.

\subsection{Analytic Definitions}

Following Pitt and Randolph's (2009, p. 841) definition of community, we define community resistance as opposition stemming from the "entirety of a given locality, including its residents, businesses, and institutions" that stand in the way of achieving local goals or policies. This definition is limited to democratic societies, and the goals we are referring to concern those promoting sustainable development in the form of higher-density living, natural resource conservation, cleaner environment, and affordable housing.

Following Forsyth (1999, p. 6), we define discretion as "appropriately distinguishing between actions and having the power to act on those judgments." According to Forsyth (1999), discretion can be positive (actors having formal power to decide) or negative (actors having no formal power, but an informal expectation that a decision will be made exists), as well as strong (actors face no constraints on decision making) or weak (greater constraints on decision making exist). Of the different types of discretion, planning decisions in the U.S. may entail more negative and weak discretion, as elected officials, executive leaders, and planning commissions tend to have more positive and strong discretion, although this depends on context (Forsyth, 1999).

Strategy is broadly defined as a plan of action to achieve an overall aim. Strategies are believed to range from purely deliberate (i.e., realized as intended) to purely emergent (i.e., realized despite intentions), with most strategies falling somewhere in between (Mintzberg \& Waters, 1985).
We therefore define discretionary strategy as involving a deliberate or emergent plan of action to achieve an aim conceived and implemented within an actor's discretionary space. From the perspective of the planner, discretionary strategies are normative-that is, they aim to encourage outcomes that are consistent with professional norms, ideals, or values. Discretionary strategies in such settings are often persuasive in nature because while they cannot compel a democratic society in a certain direction, they can prompt change through reasoning, argumentation, evidence, and course of action.

\section{Empirical Findings}

To identify perceived sources of community resistance to sustainable development and discretionary strategies planners utilize to deal with such resistance, we interviewed city planners and asked them open-ended questions about a situation in the past when people stood in their way to make a particular decision regarding a development project, and what they did to deal with this situation. We find planners face multiple sources of community resistance but also utilize a wide range of discretionary strategies aimed at persuading communities to pursue a more sustainable path in development. We explain the findings below, which reflect what was said during the interviews, backed by reviews of official planning documents.

\subsection{Sources of Community Resistance to Sustainable Development}

Achieving sustainable development involves overcoming obstacles associated with institutions, political economies, and path dependencies (Filion, Lee, Leanage, \& Hakull, 2015). Less explored are the sources of resistance to sustainability stemming from citizens, businesses, and elected officials. Table 2 lists the general sources of community resistance to sustainable development (development pressures, NIMBY-related resistance, and community distrust/lack of understanding planning), as well as more specific sources, experienced within the four cities examined. We explain each identified source in order in the following table.

\subsubsection{Development Pressures}

Development pressures have long been a key driver of urban growth and economic expansion. Harvey Molotch's seminal work on urban growth machines (Logan \& Molotch, 1987; Molotch, 1976) contends that as landbased interests (landowners, real estate agents, lawyers, newspapers, etc.) cooperate and overrepresent in local government, these interests tend to promote the growth of cities, increased land rents, and competition between cities for development. Although the growth machine theory has lacked generalizability to other countries, especially in Western Europe (Cox, 2017), there is strong 
Table 2. Sources of community resistance to sustainable development planning.

\begin{tabular}{|c|c|c|c|c|}
\hline & City A & City B & City C & City D \\
\hline \multicolumn{5}{|l|}{ Development pressures } \\
\hline Pressure to approve development projects faster & & $\mathrm{X}$ & $\mathrm{X}$ & \\
\hline Pressure for regulation or zoning rule change & & $\mathrm{X}$ & $\mathrm{X}$ & \\
\hline Pro-growth/push for economic development & & $\mathrm{X}$ & $\mathrm{X}$ & \\
\hline Developers opposed to sustainability goals & & $\mathrm{X}$ & $x$ & $x$ \\
\hline \multicolumn{5}{|l|}{ NIMBY-related resistance } \\
\hline Density concerns & $x$ & $\mathrm{X}$ & $\mathrm{x}$ & $\mathrm{x}$ \\
\hline Parking concerns & $\mathrm{x}$ & $\mathrm{x}$ & $\mathrm{x}$ & $\mathrm{x}$ \\
\hline Opposition to multifamily housing & $\mathrm{x}$ & & $x$ & $x$ \\
\hline Landowner-resident conflicts & $x$ & $\mathrm{X}$ & $\mathrm{x}$ & $x$ \\
\hline Ecological preservation & & & & $\mathrm{x}$ \\
\hline \multicolumn{5}{|l|}{ Community distrust/lack of understanding planning } \\
\hline Distrust between elected officials and planning staff & $x$ & & $\mathrm{x}$ & \\
\hline Lack of understanding zoning and approval processes & $x$ & $\mathrm{X}$ & $x$ & $\mathrm{X}$ \\
\hline Archaic view of city planning & & $\mathrm{X}$ & & \\
\hline Lack of attention to projects in early planning stages & $\mathrm{X}$ & & & \\
\hline
\end{tabular}

empirical support for developers and real estate interests promoting less-than-sustainable growth patterns in cities in the U.S. However, this depends on the institutional context that can help or hinder pro- or anti-growth interests (Hawkins, 2014b; Lubell, Feiock, \& Ramirez de la Cruz, 2009; Schneider \& Teske, 1993). This shift from Molotch's focus on landowners and land-related interests to developers and real estate firms as the primary actors in growth machines has been a fruitful approach for empirical research. As Cox (2017, p. 395) notes: "The enduring actors in the development politics of the city, the city as a growth machine, are the developers and the land development companies."

In our study, we considered development pressures to be an external force placed on planning departments to pursue development without meaningfully considering other sustainability goals. Interviewees in cities B, C, and $D$ mentioned development pressures in the form of: (1) developers pushing development projects through approval processes faster; (2) developers changing regulations or zoning laws to facilitate development; (3) cities narrowly pursuing development goals to bolster economic competitiveness; and (4) developer opposition to sustainability goals.

Planners expressed concerns over being pressured to facilitate faster project approval. Pushing development projects through administrative processes faster runs the risk of overlooking environmental, equity, safety, and aesthetic concerns. One interviewee in city $\mathrm{C}$ mentioned how developers have threatened to pull out their projects if the city could not adjust its laws to facilitate faster approval processes:

Developers say that they just can't do it. They say that they cannot make it work. And they say, 'I'll pull out everything and go to a different city'-That wouldn't have been a good situation for the city, either. They say, 'I'll fight you tooth and nail.'

Both cities $B$ and $C$, which are significantly larger than cities $A$ and $D$, experienced pro-growth pressures to narrowly pursue development and bolster economic competitiveness. Empirical research has long suggested that cities will focus on enhancing economic viability before addressing social or environmental concerns (Deslatte \& Stokan, 2019; Peterson, 1981). While such emphasis can deliver economic benefits, it also impacts future decisions and uncertainty, as a planner in city B explained:

Our city's planning and development has been very pro-development, and this encouraged all different kinds of development in the city. From an economic point of view, it was advantageous, but that has had an impact on [sustainability] decisions that have been made....I don't want to be pressured to say that it's good or bad until we can see something....In the end I probably agreed to things that I wouldn't have agreed to without that pressure [from developers]. What did we miss when we were being pressured?

Interviewees also discussed how developers have significant influence over the language in planning documents and zoning laws. In city $\mathrm{C}$ developers were able to remove language from a publicly-endorsed comprehensive plan that would have promoted social equity at the expense of developers' profits. As one planner explained:

Our [city's] comprehensive plan draft had inclusionary zoning. We had a robust public engagement process and stakeholder process, and the public supported 
it. However, the development community did not. Our community is developer-friendly. So, although the plan was written mostly, when the second subset group with developers and one of the city council members came in, they took out inclusionary zoning from the comprehensive plan.

The malleability of planning documents to developer demands is disconcerting, especially as planners in cities B, $C$, and $D$ mentioned local developers being opposed to sustainability goals. We were surprised that interviewees in cities $A$ did not mention developer pressures as a source of community resistance. It is possible that city $A$ being an older city with minimal undeveloped land and a heavier focus on infill may have helped reduce some pressure from developers.

\subsubsection{NIMBY-Related Resistance}

NIMBYism concerns locally unwanted land uses that are perceived to have a negative influence on property values, health, environment, and/or quality of life. Schively (2007) notes that there are two conflicting characterizations of NIMBYism. One is negative, as narrow-minded, self-interested actors oppose land uses that impose costs on their neighborhood even though such uses may benefit the community at large. The other is positive, as the phenomenon gives rise to grassroots citizen opposition, especially among marginalized groups facing unwanted or unjust land uses. Schively points out that the perceptions of impacts, participants, and siting processes can vary significantly among decision makers and actors affected by such decisions.

NIMBYism is generally viewed as a barrier to sustainability in the form of renewable energy deployment (Devine-Wright, 2014), higher-density living (Lewis \& Baldassare, 2010), public transit expansion (Weitz, 2008), and affordable housing (Scally \& Tighe, 2015), although this may be the opposite case in environmental justice where NIMBYism can stave off environmental hazard siting in vulnerable neighborhoods (Rabe, 1994). In our data, NIMBYism was the most prevalent source of community resistance mentioned. Interviewees in all four cities mentioned experiencing resistance to higher-density projects, such as multifamily housing, and increased scarcity of parking. As a planner in city A described:

Community groups have opposed to different areas of development of the city. This opposition has been pretty consistent in the community because our residents truly believe that this community is a sleeper or suburban community. Single-family homes in the city are greater than $85 \%$ of all residential buildings, which is significantly high. And that's what the community is used to. So, any time townhomes or apartment buildings or anything like that comes in, the community has been very outspoken about that.
Interviewees identified community resistance to multifamily housing in three of the four cities studied. A planner in city $D$, which is the smallest city in our study, mentioned: "Multifamily projects that include some affordable housing units...are dirty work around here in the public's perspective. Residents really don't understand, [and they ask,] 'Why can't you make [developers] stop building multifamily?"'

Community opposition to higher-density development was also prevalent in all four cities. In city $D$, for example, higher-density living is generally cast in a negative light among citizens. As one planner explained:

Residents don't really understand the word 'sustainability.' So, we took baby steps with all of our plans and policies where we can educate on what sustainability is. Sustainable development is maybe a little more urban-level development as far as the bad 'D-word,' density. That's a dirty word around here.

We also found NIBMY-related conflicts between landowners and residents across the four cities. A planner in city $C$ mentioned how residents opposed a new commercial development because of negative externalities associated with the development:

There was a large commercial development, and the residents did not want that development to occur. They came out to a community meeting and expressed reasons in terms of noise, light, and air quality impacts that would impact them, and claimed that [the development] was not compatible. It's probably the typical story of NIMBYism.

While less common in our data, NIMBYism also manifested in residents' ecological values that conflict with development projects. Planners in city $\mathrm{D}$, a comparatively wealthier and more educated community, mentioned a story where concerned residents pushed a developer and the city to relocate wildlife inhabiting a plot proposed for development.

\subsubsection{Community Distrust/Lack of Understanding Planning}

Perhaps the most crucial component of planning in democratic society is trust in government. Laurian (2009, p. 371) defines trust as a "mode of interpersonal relations embedded in a complex network of social relations and norms," and argues that while building trust entails dealing with obstacles and paradoxes in democratic governance, trust can be facilitated through better communication strategies.

Resistance to sustainable development planning stemming from community distrust was a common theme emerging in the interviews. Such distrust appeared to be associated with elected officials and citizens lacking understanding of planning practice. A planner in 
city A explained how distrust among elected officials may link to a lack of understanding planning practice in exercising independent professional judgment:

Council has made it very clear that they think [the planning] staff has an agenda and are unwilling to see any evidence that we bring forth....[The planning department] did a couple of parking analyses, going around to different approved apartments in the city and also in the region to see utilization rates and found that [a very high percentage of them] were pretty severely underutilized.... That [study] was just completely thrown out the window because [council] essentially said, 'We recognize that staff did this; we don't trust staff's counts.'

In addition, interviewees in all four cities mentioned the public lacking understanding of zoning and approval processes. For example, a planner in city $\mathrm{D}$ commented on how the public sometimes does not understand how zoning is approved:

There is a confusion. People say on Facebook that 'Our city is building a strip club,' or 'Our town is building a new neighborhood.' But the city does not build anything. Property owners are building it, and they have come to us....We require them to meet a number of standards.

Interviewees in cities A also mentioned citizens paying little attention to development in early stages when projects are more malleable to public input, and interviewees in city B indicated the public having an "archaic" view of city planning. Although these sentiments may not extend to the communities at large, distrust and lack of understanding planning may serve as a key barrier to encouraging sustainable development and participatory governance. One way planners aim to close the perceived trust gap and improve public understanding of planning practice is through communication strategies described in the section below.

\subsection{Discretionary Strategies Planners Use}

In addressing our second research aim, we contribute to the literatures on administrative discretion and sustainable development planning by zeroing in on the strategies planners use within their discretionary space to persuade their community towards sustainable development. Our interviews yielded five general strategies that planners employ, as well as a number of sub-categories, reported in Table 3.

\subsubsection{Coordination and Networking}

One key strategy for building capacity for planning sustainable development is collaboration (Hawkins, Krause, Feiock, \& Curley, 2016; Innes \& Booher, 1999, 2003). We learned from our interviews that city planning offices informally engage in interdepartmental coordination and seek out internal leadership buy-in when attempting to build capacity and support for their recommendations.

Interviewees in all four cities mentioned using coordination between departments to combat organizational silos, share knowledge, and better address new problems. A planner in city B discussed how interdepart-

Table 3. Planners' discretionary strategies for encouraging sustainable development.

\begin{tabular}{|c|c|c|c|c|}
\hline & City A & City B & City C & City D \\
\hline \multicolumn{5}{|l|}{ Coordination and networking } \\
\hline Interdepartmental coordination & $\mathrm{X}$ & $\mathrm{X}$ & $\mathrm{X}$ & $\mathrm{X}$ \\
\hline Seeking out internal leadership buy-in & $\mathrm{X}$ & & $\mathrm{X}$ & $\mathrm{X}$ \\
\hline \multicolumn{5}{|l|}{ Expanding outreach, communication, and education } \\
\hline Educating council members and citizens & $\mathrm{X}$ & $\mathrm{X}$ & $\mathrm{X}$ & $\mathrm{X}$ \\
\hline Promoting participatory decision making & $\mathrm{x}$ & $\mathrm{X}$ & $\mathrm{x}$ & $\mathrm{x}$ \\
\hline Publishing a monthly newsletter & & & & $\mathrm{x}$ \\
\hline Engaging in social media exchange & $\mathrm{x}$ & & $x$ & \\
\hline \multicolumn{5}{|l|}{ Utilizing data and evidence } \\
\hline Performing data analysis and visualization & $\mathrm{X}$ & $\mathrm{X}$ & $\mathrm{X}$ & \\
\hline Providing ample documentation and evidence & $\mathrm{x}$ & $\mathrm{X}$ & $x$ & $\mathrm{x}$ \\
\hline \multicolumn{5}{|l|}{ Changing formal/informal rules } \\
\hline Updating zoning codes & $x$ & $\mathrm{X}$ & $\mathrm{X}$ & $\mathrm{X}$ \\
\hline Utilizing administrative zoning & $\mathrm{x}$ & & $\mathrm{X}$ & \\
\hline Developers engaging the community to resolve conflicts & $\mathrm{X}$ & & & \\
\hline Council resolving disagreements before directing staff & & & & $\mathrm{x}$ \\
\hline \multicolumn{5}{|l|}{ Being transparent, neutral stewards } \\
\hline Being an honest, neutral broker & $\mathrm{X}$ & & $\mathrm{X}$ & $\mathrm{X}$ \\
\hline Promoting transparency & $\mathrm{X}$ & $\mathrm{X}$ & $\mathrm{X}$ & $\mathrm{x}$ \\
\hline
\end{tabular}


mental coordination prevents developers from strategically playing one department against another when seeking information:

To make sure zoning codes and residential standards work for everyone, we had a weekly-basis meeting with staff, managers and directors of the planning department and additional staff from other departments for six months....Especially on these large projects, we're trying to minimize side effects, and every department sits at the table when something new is coming at us. This doesn't allow the developers to hit one department and fish for answers. And that coordination has really grown in the last year or two.

Planners also mentioned seeking internal leadership buyin when making discretionary recommendations. They suggested that the support from city leadership is especially valuable when situations remain stymied by a lack of consensus. A planner from city $C$ described how making an unpopular yet necessary decision to shut down a homeless shelter project due to large cost overruns was realized with support from city leadership:

There was a shelter project [with] significant costs and architectural engineering, permit fees, plan development, reviews, etc. But it was clear to me that it was not a good project to move forward.... thought it was better to call it off, which I did. So, I went to the city leadership making that decision public, and I had the full support to go ahead. I would say, at least internally, the leadership is here.

Planning organizations may be able to achieve greater information sharing and collective action at higher levels of scale through intergovernmental collaboration (Hawkins et al., 2016), but our findings suggest that coordinating within city governments and seeking out internal leadership buy-in may be more common discretionary strategies to promote internal planning capacity for sustainable development.

\subsubsection{Expanding Outreach, Communication, and Education}

Communication is an essential tool for planners. Crafting logical arguments, persuading decision makers with captivating narratives, negotiating between conflicting interests, and listening to citizen stakeholders' concerns are all empirically supported actions that promote planning practice in democratic society (Forester, 1989; Hoch, 1994; Moore \& Elliott, 2016).

Communicating with, reaching out to, and educating community stakeholders were identified as key discretionary strategies for persuading sustainable development. Interviewees in all four cities indicated they often educate city council members and the public, and engage the community in discussing planning issues. While planners in city $D$ described how they engaged the community when incorporating density into their master plan, city $B$ institutionalized community education and outreach by establishing a planning academy for residents wishing to be on the planning commission:

We [the planning department] were trying to help [residents] understand the city and how important the environment is, and how important these decisions that [the planning commission is] negotiating right now....They didn't even know about boards and commissions. They wanted to engage with the city; they didn't know how. Maybe it was just to complain about their water bill, but they ended up doing something else.

While investing in a planning academy may be no trivial feat, small changes can also help educate stakeholders and promote information dissemination. City $D$, for example, started a monthly newsletter to inform citizens about sustainable development and mitigate political controversies. As one planner described:

My mantra has always been, 'We need to educate better.' We created a section called 'Planning and Building a Sustainable City' in our monthly newsletter. So, we'll do monthly articles on this, whatever the controversy is....You just try to stay one step ahead of it.

Planners in cities $\mathrm{A}$ and $\mathrm{C}$ also mentioned how they rely on social media to better gauge local politics, values, and preferences around planning issues. According to a planner in city $A$ :

Facebook groups have been most useful because people are sharing a lot of great information there, and having open dialogue with each other. There are conflicts within the groups as far as people's opinions on different projects. And it's kind of neat to see that play out.

However, a planner in city D offered a caveat about the drawbacks associated with planners' use of social media, as citizen input via social media can reflect skewed or biased views on planning issues, and mentioned avoiding social media when possible.

While there may be numerous approaches to implementing outreach, communication, and education strategies focused on promoting citizen understanding of and participation in planning, all strategies should fit the needs and capabilities of the planning organization and the community (Burke, 1968).

\subsubsection{Utilizing Data and Evidence}

If planning is about storytelling (Hoch, 1994), then the use of data, technology, and scientific evidence can 
make planners' stories more compelling and persuasive if used appropriately (Ramasubramanian \& Albrecht, 2018). Interviewees in all four cities mentioned using data and evidence to overcome community resistance. Interviewees in three out of four cities said that data and visualization are crucial for developing better narratives for communicating to the public. A planner in city B described how visualization can help when planners know what their audience is looking for:

We use a lot of visuals that were recognizable by the audience that we're speaking to. Trying to explain how the zoning code is changing from $X$ to $Y$ is difficult. So, what we tried to do was use visualization and simulation. We show visually how lots are going to be laid out or what changes needed to be made if we apply the new code. The audience will be more familiar with the project.

Another planner in city B added: "In a recent presentation, we pulled walk score, bike score, household income data and so on, and we showed developers how nice that street would be. When we put data together and show visual projection, people are persuaded."

Across all four cities planners also mentioned providing documentation and evidence to support their recommendations to the city council and planning commission. As one planner in city A mentioned: "We have been trying to find academic research that supports [sustainable development] points of view. We wanted to convince council members that this [study] isn't just presenting a viewpoint."

Data, visualization, and evidence, however, will likely only take planners so far in encouraging sustainable development. Campbell (2012) teaches us that presenting analysis is not meaningful in the planning context unless it is accompanied by synthesis or judging what action should be taken in a given situation; that is, to be impactful, planners need to link "knowledge to action."

\subsubsection{Changing Formal/Informal Rules}

Bureaucrats changing formal and informal rules to meet the demands of their job is a classic discretionary strategy (Lipsky, 1980). From our interviews we found all four cities regularly update zoning codes to steer development in a more sustainable direction. For example, after receiving several requests for waivers regarding changes to standard residential lot sizes, city $B$ reviewed those standards to promote sustainable development. As one planner stated:

We're now updating our whole code. And as part of that, we're updating standards for new residential homes, specifically smaller lots. And there's been a lot of pushback from the development community, specifically home builders on those standards....It's really a question of the quality of housing, design, and aesthetic of the neighborhood. So, if you've got the smaller lots, you can add development standards, architecture, that kind of stuff to increase the overall aesthetic of the neighborhood.

Interviewees in cities $A$ and $C$ also said that extensive use of a planned unit development (PUD) process have created challenges. PUD is a land regulatory process requiring planning commissions to hold public hearings. Although PUDs promote transparency and public oversight, they can cause significant delays in development projects. Interviewees in city A suggested that the PUD process has reduced trust among community stakeholders: "We've kind of gotten ourselves into a situation where we have enabled mistrust because we put all projects through a public hearing phase that allows people to scrutinize things." By putting more projects consistent with sustainability principles through administrative processes, planning departments can more easily avoid community resistance and lengthy development delays associated with PUDs.

While zoning changes and PUDs are formal rules, interviewees in cities $A$ and $D$ also identified the establishment of informal rules. To resolve conflicts between landowners and residents, city A encourages developers to reach out to the community before the review process: "We encourage our applicants to actively reach out to the community and communicate at the neighborhood meetings beyond the boundaries. Even if this isn't required, it's still a good idea....We're always pushing for more transparency."

Planners in city $D$, on the other hand, established an informal expectation for their city council to resolve conflicts before directing planning staff, which led to administrative efficiencies from the perspective of planners.

\subsubsection{Being Transparent, Neutral Stewards}

Openly admitting that planners are not the people whose intentions count may help planners circumvent community resistance and share blame when things go wrong (Wildavsky, 1973). Planners in all four cities made it clear that their job is to work for the community and incorporate local knowledge into planning decisions and processes. As a planner in city $D$ pointed out:

We educate the community, and we push for the right thing. But we can't force the community to be something that it's not. So, we can guide them to the right answers, and we can push them as far as we think it is appropriate. But in the end, we work for the community.

A planner in city $\mathrm{C}$ echoed this sentiment when stating: "Our job is to be an honest broker. This community is not environmental activist-That's just not the DNA of this community....We try to be transparent and as open as possible." 
The planners we interviewed appeared to share a normative value that, in democratic society, planners' technical knowledge as to what should or ought to be done is subordinate to what the community wants. While planners may have predispositions for directing communities towards sustainability due to their technical expertise, the application of such knowledge is kept in check by citizens' demands. Transparent, neutral stewardship-or being on "honest broker" who integrates diverse stakeholder perspectives and avoids advocating for a particular side (Pielke, 2007)-may be an effective strategy for guiding communities toward development goals, as honest brokerage has been found to enhance collaboration in sustainability management (Duff et al., 2009).

\section{Discussion}

Although technical skills are crucial for planning sustainable development in a rapidly urbanizing world, planners' political, social, and communication skills will be even more valuable as competition for scarce resources grows. Planners are not merely technicians charged with preparing esoteric plans, reports, and documents; they are political actors with varying degrees of administrative discretion in how they help shape the communities they serve (Forsyth, 1999). This article identified key sources of community resistance to sustainable development and discretionary strategies planners use to overcome such resistance. The findings build on decades of research suggesting that planners engage in discretionary activity and play an important role in shaping democratic society (Forester, 1982, 1989; Hoch, 1994; Taylor, 1998).

This study has some implications for planning practice. First, it would be unhelpful to think of the sources of community resistance and the discretionary strategies identified in this article in isolation. In reality, planners face community resistance from a multitude of sources, which are interwoven with other sources of resistance occurring simultaneously. This is why it is critical for planners to comprehensively assess, within their cognitive limits, the dynamic political and cultural landscape and tackle obstacles with a portfolio of strategies. Any discretionary strategy employed in isolation is likely too limited to have any substantial effect at overcoming longstanding barriers to sustainable development, especially in communities unsympathetic to sustainability.

Second, the sources of community resistance to sustainable development are complex and extend beyond NIMBYism. They also occur at the macro level (e.g., development pressures) and are inherent conflicts in democratic governance (e.g., distrust between planning experts and citizens). Employing strategies to facilitate communication, dialogue, and knowledge sharing among planners, elected leaders and citizens is essential. But communication is not the only structural impediment to sustainable development planning. Adjusting rules such as utilizing more administrative zoning in lieu of PUD processes, where appropriate, and urging developers to go above and beyond neighborhood engagement and assessment requirements could be promising ways to promote sustainability within planners' discretionary space.

Finally, the discretionary strategies planners appear to utilize could be enhanced with additional training in the social science and policy analysis and management disciplines. Intellectual and practical skills in social network analysis, evidence-based methodology, data visualization, public management, and public relations and rhetoric could go a long way in helping planners in persuade their communities in a more sustainable direction.

For future research, large- $\mathrm{N}$ assessments will offer a wider range of the types of community resistance and discretionary strategies in sustainable development planning. Studies over time and across institutional contexts are also needed to examine the effectiveness of these strategies in promoting more sustainable development patterns, and how these strategies work or do not work under different constraints. Especially, researchers can look more carefully at how different citizen demands and political preferences of communities shape the effectiveness and duration of discretionary strategies that planners use.

\section{Conclusion}

This article aimed to better understand the sources of community resistance to sustainable development and the discretionary strategies that planners use to overcome such resistance. Investigating four Colorado cities experiencing growth and development change, we identified diverse sources of community resistance to sustainable development planning, as well as a multitude of strategies that planners use within their discretionary space to overcome such resistance. Developer-induced pressures, NIMBY-related concerns over increased density, and distrust and misunderstanding of planning were common sources of community resistance observed across the case cities. However, at their discretion, planners utilize a host of strategies aimed overcoming such resistance, including interdepartmental coordination, educating council members and residents, providing data and evidence, changing formal and informal rules, and serving as honest, transparent brokers in planning processes.

This study is limited by its focus on four cities in a single region within one U.S. state, and thus we make no claims about the generalizability of the findings. Also, interviewing only local planning staff prevented us from gaining different perspectives from city council members, developers, and residents. We encourage researchers to build on these findings and further investigate the discretionary strategies planners employ, and the impacts of these actions on sustainable development over time and across contexts. 


\section{Acknowledgments}

We would like to thank the 26 planners and the communities that support them, who generously participated in this study and provided their insights. We would also like to thank the Office of Research Services and the School of Public Affairs at the University of Colorado Denver for supporting this research.

\section{Conflict of Interests}

The authors declare no conflict of interests.

\section{References}

American Planning Association. (2016). American institute of certificated planners (AICP) code of ethics and professional conduct. Chicago, IL: American Planning Association.

Arnstein, S. R. (1969). A ladder of citizen participation. Journal of the American Institute of Planners, 35(4), 216-224.

Brundtland, G. H. (1987). Our common future: The world commission on environment and development. Oxford: Oxford University Press.

Burke, E. M. (1968). Citizen participation strategies. Journal of the American Institute of Planners, 34(5), 287-294.

Campbell, H. (2002). Planning: An idea of value. Town Planning Review, 73(3), 271-288.

Campbell, H. (2012). Planning to change the world: Between knowledge and action lies synthesis. Journal of Planning Education and Research, 32(2), 135-146.

Campbell, S. (1996). Green cities, growing cities, just cities? Urban planning and the contradictions of sustainable development. Journal of the American Planning Association, 62(3), 296-312.

Corbin, J., \& Strauss, A. (2015). Basics of qualitative research: Techniques and procedures for developing grounded theory (4th ed.). San Jose, CA: Sage.

Corburn, J. (2003). Bringing local knowledge into environmental decision making: Improving urban planning for communities at risk. Journal of Planning Education and Research, 22(4), 420-433.

Cox, K. R. (2017). Revisiting 'the city as a growth machine.' Cambridge Journal of Regions, Economy and Society, 10(3), 391-405.

Deslatte, A., \& Stokan, E. (2019). Hierarchies of need in sustainable development: A resource dependence approach for local governance. Urban Affairs Review, 55(4), 1125-1152.

Deslatte, A., \& Swann, W. L. (2016). Is the price right? Gauging the marketplace for local sustainable policy tools. Journal of Urban Affairs, 38(4), 581-596.

Devine-Wright, P. (Ed.). (2014). Renewable energy and the public: From NIMBY to participation. London: Routledge.

Duff, G., Garnett, D., Jacklyn, P., Landsberg, J., Ludwig, J.,
Morrison, J., . . . Whitehead, P. (2009). A collaborative design to adaptively manage for landscape sustainability in north Australia: Lessons from a decade of cooperative research. Landscape Ecology, 24(8), 1135-1143.

Filion, P., Lee, M., Leanage, N., \& Hakull, K. (2015). Planners' perspectives on obstacles to sustainable urban development: Implications for transformative planning strategies. Planning Practice and Research, 30(2), 202-221.

Fischer, F. (2000). Citizens, experts, and the environment: The politics of local knowledge. Durham, NC: Duke University Press.

Forester, J. (1980). Critical theory and planning practice. Journal of the American Planning Association, 46(3), 275-286.

Forester, J. (1982). Planning in the face of power. Journal of the American Planning Association, 48(1), 67-80.

Forester, J. (1989). Planning in the face of power. Berkeley, CA: University of California Press.

Forsyth, A. (1999). Administrative discretion and urban and regional planners' values. Journal of Planning Literature, 14(1), 5-15.

Godschalk, D. R. (2004). Land use planning challenges: Coping with conflicts in visions of sustainable development and livable communities. Journal of the American Planning Association, 70(1), 5-13.

Goetz, A. (2013). Suburban sprawl or urban centres: Tensions and contradictions of smart growth approaches in Denver, Colorado. Urban Studies, 50(11), 2178-2195.

Hawkins, C. V. (2014a). Planning and competing interests: Testing the mediating influence of planning capacity on smart growth policy adoption. Journal of Environmental Planning and Management, 57(11), 1683-1703.

Hawkins, C. V. (2014b). Competing interests and the political market for smart growth policy. Urban Studies, 51(12), 2503-2522.

Hawkins, C. V., Krause, R. M., Feiock, R. C., \& Curley, C. (2016). Making meaningful commitments: Accounting for variation in cities' investments of staff and fiscal resources to sustainability. Urban Studies, 53(9), 1902-1924.

Hoch, C. (1994). What planners do: Power, politics, and persuasion. Chicago, IL: American Planning Association.

Innes, J. E., \& Booher, D. E. (1999). Consensus building and complex adaptive systems: A framework for evaluating collaborative planning. Journal of the American Planning Association, 65(4), 412-423.

Innes, J. E., \& Booher, D. E. (2003). The impact of collaborative planning on governance capacity (Working Paper 2003/03). Berkeley, CA: Institute of Urban \& Regional Development, University of California, Berkeley.

Lake, R. W. (1993). Planners' alchemy transforming NIMBY to YIMBY: Rethinking NIMBY. Journal of the 
American Planning Association, 59(1), 87-93.

Laurian, L. (2009). Trust in planning: Theoretical and practical considerations for participatory and deliberative planning. Planning Theory \& Practice, 10(3), 369-391.

Lewis, P. G., \& Baldassare, M. (2010). The complexity of public attitudes toward compact development: Survey evidence from five states. Journal of the American Planning Association, 76(2), 219-237.

Lipsky, M. (1980). Street-level bureaucracy: Dilemmas of the individual in public services. New York, NY: Russell Sage Foundation.

Logan, J. R., \& Molotch, H. L. (1987). Urban fortunes: The political economy of place. Berkeley, CA: University of California Press.

Lubell, M., Feiock, R. C., \& Handy, S. (2009). City adoption of environmentally sustainable policies in California's central valley. Journal of the American Planning Association, 75(3), 293-308.

Lubell, M., Feiock, R. C., \& Ramirez, E. (2005). Political institutions and conservation by local governments. Urban Affairs Review, 40(6), 706-729.

Lubell, M., Feiock, R. C., \& Ramirez de la Cruz, E. E. (2009). Local institutions and the politics of urban growth. American Journal of Political Science, 53(3), 649-665.

Mintzberg, H., \& Waters, J. A. (1985). Of strategies, deliberate and emergent. Strategic Management Journal, 6(3), 257-272.

Mitchell, D., Attoh, K., \& Staeheli, L. (2015). Whose city? What politics? Contentious and non-contentious spaces on Colorado's Front Range. Urban Studies, 52(14), 2633-2648.

Molotch, H. (1976). The city as a growth machine: Toward a political economy of place. American Journal of Sociology, 82(2), 309-332.

Moore, K. R., \& Elliott, T. J. (2016). From participatory design to a listening infrastructure: A case of urban planning and participation. Journal of Business and Technical Communication, 30(1), 59-84.

Owens, S. (1994). Land, limits and sustainability: A conceptual framework and some dilemmas for the planning system. Transactions of the Institute of British Geographers, 19(4), 439-456.

Peterson, P. E. (1981). City limits. Chicago, IL: University of Chicago Press.

Pielke, R. A., Jr. (2007). The honest broker: Making sense of science in policy and politics. New York, NY: Cambridge University Press.

Pitt, D., \& Randolph, J. (2009). Identifying obstacles to community climate protection planning. Environment and Planning C: Government and Policy, 27(5), 841-857.

Portney, K. E., \& Berry, J. M. (2010). Participation and the pursuit of sustainability in US cities. Urban Affairs Review, 46(1), 119-139.

Rabe, B. G. (1994). Beyond NIMBY: Hazardous waste siting in Canada and the United States. Washington, DC: Brookings Institution.

Ramasubramanian, L., \& Albrecht, J. (2018). Essential methods for planning practitioners: Skills and techniques for data analysis, visualization, and communication. Cham: Springer International.

Scally, C. P., \& Tighe, J. R. (2015). Democracy in action? NIMBY as impediment to equitable affordable housing siting. Housing Studies, 30(5), 749-769.

Schively, C. (2007). Understanding the NIMBY and LULU phenomena: Reassessing our knowledge base and informing future research. Journal of Planning Literature, 21(3), 255-266.

Schneider, M., \& Teske, P. (1993). The antigrowth entrepreneur: Challenging the "equilibrium" of the growth machine. The Journal of Politics, 55(3), 720-736.

Tabachnik, S. (2018, December 24). With 80,000 new residents, Colorado is the seventh-fastest growing state in the U.S. The Denver Post. Retrieved from https://www.denverpost.com/2018/12/24/coloradopopulation-growth

Taylor, N. (1998). Urban planning theory since 1945. Thousand Oaks, CA: Sage.

Wallis, A. (2008). Developing regional capacity to plan land use and infrastructure. In D. K. Hamilton \& P. S. Atkins (Eds.), Urban and regional policies for metropolitan livability (pp. 92-125). New York, NY: M.E. Sharpe.

Weitz, R. (2008). Who's afraid of the big bad bus? NIMBYism and popular images of public transit. Journal of Urbanism, 1(2), 157-172.

Wheeler, S. M. (2000). Planning for metropolitan sustainability. Journal of Planning Education and Research, 20(2), 133-145.

Wildavsky, A. (1973). If planning is everything, maybe it's nothing. Policy Sciences, 4(2), 127-153.

Yin, R. K. (2014). Case study research: Design and methods (5th ed.). Thousand Oaks, CA: Sage.

Yin, R. K. (2016). Qualitative research from start to finish (2nd ed.). New York, NY: The Guilford Press.

\section{About the Authors}

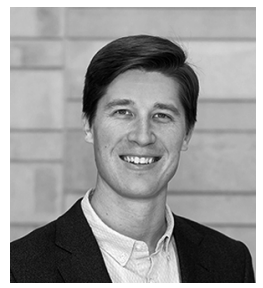

William L. Swann is an Assistant Professor in the School of Public Affairs at the University of Colorado Denver. He holds a PhD in Public Administration from Florida State University. His research focuses on the planning, management, and governance of urban sustainability, as well as the health and environmental impacts associated with local sustainability policies. 


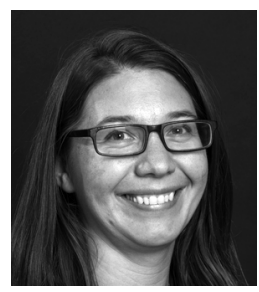

Shelley McMullen is a Dual Degree Master of Public Administration and Master of Urban and Regional Planning at the University of Colorado Denver. She has an undergraduate degree in civil engineering from Colorado School of Mines and experience consulting for both private land development and public transportation projects. She currently works as a Research Assistant studying recovery from natural hazards, and as a Public Outreach Consultant for a transportation planning and engineering firm.

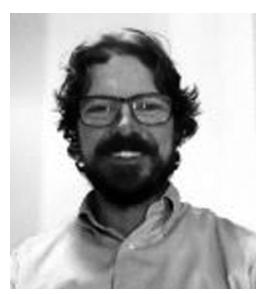

Dan Graeve is a Master of Public Administration Student in the School of Public Affairs at the University of Colorado Denver. He currently works as Support Staff for the Environmental Quality Units of the Colorado Attorney General's Office. He previously owned and operated True Roots Farm, LLC, an urban vegetable farm in Wheat Ridge, Colorado.

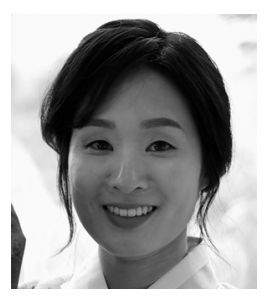

Serena Kim is a Scholar in Residence in the School of Public Affairs at the University of Colorado Denver. She holds a PhD in Public Administration from Florida State University. Her research focuses on renewable energy policy, collective action, and environmental politics. Her research has appeared in Policy \& Politics and The Journal of Environment \& Development. 